\title{
THE WAYS OF ENHANCING THE EFFECTIVENESS OF HUMAN CAPITAL IN INTERNATIONAL TOURIST COMPANIES
}

\author{
LASHARI KURDASHVILI \\ PhD Student of Business \\ Administration at Ivane Javakhishvili Tbilisi State University
}

https://doi.org/10.35945/gb.2017.03.017

KEYWORDS: HUMAN CAPITAL, TOURISM INDUSTRY, INTERNATIONAL TOURISM, HUMAN RESOURCE MANAGEMENT

Work force and human capital are, in our view, those leading factors, in which Georgia and companies operating in its area, are able to build their own competitive advantage. This allows Georgian companies to take advantage by implementing advanced management methodology to get a huge economic effect on the use and development of human resources and personnel potential. Estimated methodology includes positively emphasizing leading western European concerns in the field of human resource management and considers the issues that have not yet been resolved within the new paradigm of management. In particular, it is about the relationship between the employee personal goals and strategic goals of the company, not only in realization of the strategy of the company, but in its formation.

The Georgian branches of international companies use the concept of an integrated management strategy that does not have Western European competitors, giving them an effective tool to win a competitive battle for the moment in Georgian market, and in future as well as foreign.

The first stage of the integrated management concept of the strategy offered by us is the development of the company's strategy, where the research companies clearly define the of creating competitive advantage and achieving international competitiveness. The next step is to develop the indicators balanced system that will be transferred to the strategy of specific operative and operational measures. These two phases of the integrated strategy management concept are conducted only if there is a prerequisite for changes in the company's strategy. In contrast, the next stages of the concept are carried out on a regular basis, and they are implemented within a certain period of time.

At the beginning of every period of the company's activity, the goals should be set in a balanced scorecard. Individual goals of managers, personnel and subordinate subdivisions would be derived from the Company's objectives and to applied for their achievement. Upon completion of the period the goals of the Company, the goals of the subdivisions and the personal goals of the heads and the subordinate ones would be evaluated. In parallel, the assessment of the head and staffpotential should be evaluated for the purpose of working with this conception. Based on the results of the assessment of potential goals achieved, the decision on the capacity of the employee's potential and the amount of compensation for its labor will be taken. This decision is aimed at the realization of company strategy and increasing its international competitiveness.

In case of detecting significant deviations from the planned performance in the results shown by the employee (as in the case of decreasing and increasing), it is necessary to discuss the causes of the incident together with the head. Depending on the diagnostic causes results of the deviation and the external factors causing them, it is possible to adjust the strategy or to elaborate a new strategy and create a new balanced system of targeted data. If the results of the work for the reporting period prove the correctness of the strategy, then there is no strategy adjustment, but the set goals for the future has to be realized. The alleged concept scheme of Strategy integrated management, which aims to increase the international competitiveness of research organizations, is presented on the chart 1.

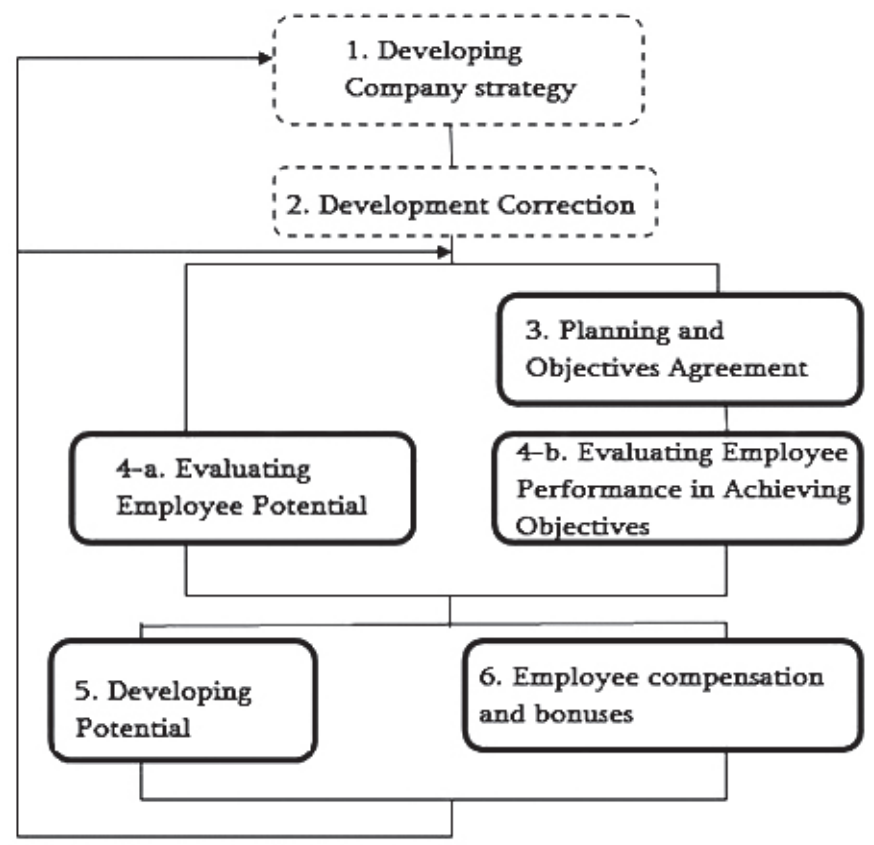

Chart 1. Strategy Integrated Management Concept Scheme, which's goal is to achieve international competitiveness

Methodology of potential assessment and development is the most important for the research firms from the listed methodology.

However, unlike Western European and American potential assessment methodologies the goal of which is to reveal the direction of the employee's potential development, the methodology proposed by the author provides methodology includes personnel working realities in Georgian companies and has the second goal - to comply with the employee's position Rate. While Western companies consider the developing potential assessment methodology the compliance of the 
employee with the position of the employee. In case of using these technologies when entering the Georgian market, Western companies would have the biggest problem if they have purchased already existing enterprises. Not surprisingly, when purchasing Georgian tourism company, they were hoping for local managers' competence, working experience in tourism business and private ties in regions. This results in financial loss and loss of position on the market.

Georgian economy strongly requires the change in the quality and structure of human capital. But neither the population nor the enterprises have the necessary resources to do so. A locked circle is created: On one hand, the enterprises can not achieve maximization of profits and then apply the part of their assets to improve their own quality, and on the other hand, no one spends funds on educating low-qualification staff and improving their qualifications, while the organizations have no means to do so. In our view, the prerogative of the solution of this vicious node belongs to the State, it is unrealistic to deal with such a problem without interference. In general, the functions of the State are as follows:

- Development of human capital reproduction policies at State level;

- Introduce and implement relevant administrative and legal regulations;
- Involve non-governmental organizations and enterprises in the field of human capital reproduction, creating a regime of support for them;

- Coordinate activities of associations and associations of the population, government and non-governmental enterprises and their interests within the framework of social partnership.

\section{CONCLUSION}

One of the main factors in progress of any tourism industry component is the development of human capital. Employees continue education providing rapid grow of the Georgian tourism industry in region and increasing of sector's competitiveness.

As the human capital intensifies competitive positions in the labor market: the better the educational base, the higher the level of economic activity, the less unemployment risk, or the job duration, the choice of job options and high mobility. The educated work force is more successfully adapted to technological and social changes, more active in the process of acquiring new knowledge and qualifications, achieving greater success in scientific-technical progress.

\section{REFERENCES:}

1. Hilb, Martin, TransnationalesManagementderHuman-Ressourcen.-2.Aufl.-Neuwied-Kriftel, 2002

2. Lvov D. Systemresourceof the economy.Статья. Social Sciences, v. 42, 2011№ 3

3. Meskhia I., Tourism Business Environment in Georgia: Analysis and Predictions, Journal "Business and Management", 2010, p 215.

4. Schultz T.W. Investmentin HumanCapital.N.Y.;L.,1971. P. 125-12

5. Smeral,Egon:DieZukunftdesinternationalenTourismus:Entwicklungsperspektivenfurdas21. Jahrhundert- Wien: LINDEVERLAG, 2003

6. Travel and Tourism Competitiveness Report, 2015, http://reports.weforum.org/travel-and-tourism-competitiveness-report-2015 


\section{THE WAYS OF ENHANCING THE EFFECTIVENESS OF HUMAN CAPITAL IN INTERNATIONAL TOURIST COMPANIES}

\section{LASHARI KURDASHVILI}

https://doi.org/10.35945/gb.2017.03.017

PhD Student of Business

Administration at Ivane Javakhishvili Tbilisi State University

KEYWORDS: HUMAN CAPITAL, TOURISM INDUSTRY, INTERNATIONAL TOURISM, HUMAN RESOURCE MANAGEMENT

\section{SUMMARY}

In recent years, tourism has become one of the most dynamically developing priority direction of Georgian economy. Tourism and hospitality industry attractiveness is due to the country's unique diversity of natural resources, cultural and historical monuments, sea and mountain resorts, curative mineral and thermal waters, favorable geographic location and many other positive factors. However, today's post-Soviet Georgia tourism industry is still weak and is in formation-development process. State government realized significant and positive measures to support tourism sector. Improved legal framework, introduced preferential taxes, tourism businesses became available for sale of state and bank loans, foreign investment was attracted to the winter ski resorts, hotels, holiday homes, roads and other tourism infrastructure facility constructions.

The author believes that tourism is one of the most dynamic sectors of Georgian economy in recent decades. The objectives of this foundation are: the unique natural resources, convenient geographical location and other factors, which contribute to the attractiveness of Georgia.

The paper discusses that the main condition for the development of enterprises of hospitality industry is human capital, shows that the continuous education employees of this area is an important factor in the reproduction of human capital. 